\title{
Clostridium aurantibutyricum (n.sp.): A Pink Butyric Acid Clostridium
}

\author{
BY ESTHER HELLINGER \\ Daniel Sieff Research Institute, Rehovoth, Palestine
}

SUMMARY: A pink, butyric acid-producing Clostridium isolated by Ch. Weizmann from South African hibiscus stems is described. It ferments sucrose, glucose, lactose, maltose, galactose, xylose, starch, but not cellulose, inulin, mannitol, glycerol and sorbitol.

The main products of fermentation of maize and glucose are butyric and acetic acids; acetone, butanol, ethanol and isopropanol are produced in slight or moderate amounts, lactic acid, formic acid and acetylmethyl-carbinol only in slight or negligible amounts. In its partial diastatic action on maize mashes and in the composition of its resultant metabolic products the new organism resembles members of the so-called butyric group of clostridia; but it differs markedly in liquefying gelatin.

In certain morphological and physiological features the organism resembles two orange-coloured clostridia, $\mathrm{Cl}$. felsineum and $\mathrm{Cl}$. roseum (both belonging to the so-called butylic group), but is readily distinguishable from them. The two butylic organisms have a complete diastatic action on maize and butanol is the chief product of fermentation. The new organism is also distinguishable by its inability to ferment inulin and to disintegrate potato slopes.

On the basis of this evidence the organism is considered to be a new species, for which the name $C l$. aurantibutyricum is suggested.

A pink organism, isolated by Ch. Weizmann in May 1939 from a sample of South African hibiscus stems, produced a distinct red coloration on maize mash, gave red colonies on nutrient glucose agar and produced butyric and acetic acids, and small quantities of neutral solvents from sugar, for the complete fermentation of which chalk was required. It produced spores which withstood $2 \mathrm{~min}$. heating at $100^{\circ}$.

A number of these cultures, designated W45, was investigated after they had been sealed for six to seven months. Some were still viable when subcultured in yeast glucose medium at $37^{\circ}$, but none survived heating for $1-2 \mathrm{~min}$. at $100^{\circ}$, nor for several minutes at $80^{\circ}$. Cultures in maize mash showed active gassing, a definite pink coloration and a good although incomplete diastatic action. The so-called head of solid particles of mash, brought to the surface by the active evolution of gas, sank when the gassing had subsided. The cultures consisted of actively motile rods and clostridia bearing subterminal spores. On yeast glucose agar slopes under anaerobic conditions more or less regular, orange-pink granular colonies were produced (Pl. 1, A). Preliminary experiments showed that the organism dissimilated carbohydrates, producing good yields of butyric and acetic acids and slight amounts of neutral volatile products, such as acetone, butanol, ethanol and isopropanol. These data, and especially the prevailing acidic nature of the fermentation products, tend to 
align the pink organism with the so-called butyric clostridia rather than with the butylic bacteria.

Chromogenic clostridia are not unknown. Two red chromogens have been described, viz. Clostridium felsineum Carbone \& Tomolato (Carbone \& Tomolato, 1917) a true retting organism from retting flax, and $\mathrm{Cl}$. roseum McCoy \& McClung (McCoy \& McClung, 1935), found occasionally with $\mathrm{Cl}$. acetobutylicum. Because of their special ability to produce high yields of acetone and butanol from starch mashes these two chromogens are grouped with the butylic organisms. No record of a pink butyric organism could be found in the literature except one by McClung (1942) who reported the isolation of some pigmented butyric types from soil and mud. This, naturally, stimulated a close study of the morphology, cultural aspects and physiological properties of the new pink butyric Clostridium, with special reference to its taxonomy and nomenclature.

\section{DESCRIPTION OF THE ORGANISM}

\section{Morphology}

Vegetative cells. Motile, medium and long rods; rounded ends; singly and in short or fairly long chains. Spore-bearing cells motile, mostly spindle-shaped (Pl. 1, B). Good sporulation at $30^{\circ}$ on $5 \%$ maize, but scanty at $37^{\circ}$, becoming negligible after several subculturings. Tendency for better sporulation on $1 \%$ than $5 \%$ maize at $37^{\circ}$.

Endospores. Subterminal and oval.

Table 1. Measurements of vegetative cells, etc., on yeast glucose agar

\begin{tabular}{|c|c|c|c|c|}
\hline & \multicolumn{2}{|c|}{ Limits of size } & \multicolumn{2}{|c|}{ Average size } \\
\hline & $\begin{array}{c}\text { Length } \\
(\mu .)\end{array}$ & $\begin{array}{c}\text { Width } \\
(\mu .)\end{array}$ & $\begin{array}{c}\text { Length } \\
(\mu .)\end{array}$ & $\begin{array}{c}\text { Length } \\
(\mu .)\end{array}$ \\
\hline $\begin{array}{l}\text { Rods : } \\
\text { (1) } 30^{\circ}\end{array}$ & & & & \\
\hline (1) $30^{\circ}$ & $2 \cdot 8-8 \cdot 0$ & $0.55-0.6$ & 4.7 & 0.58 \\
\hline (2) $37^{\circ}$ & $4 \cdot 0-17 \cdot 0$ & $0.5-0.55$ & $9 \cdot 4$ & 0.51 \\
\hline Clostridia & $5 \cdot 5-10 \cdot 5$ & $0.9-1 \cdot 1$ & $6 \cdot 9$ & 1.06 \\
\hline Spores & $1 \cdot 9-2 \cdot 4$ & $0 \cdot 85-1 \cdot 1$ & $2 \cdot 18$ & 0.97 \\
\hline
\end{tabular}

Flagella. Peritrichous.

Staining reactions. Young cultures Gram-positive. Lugol's iodine: young vegetative cells stain yellow, granulose in clostridia stains blue-violet.

\section{Fermentation of carbohydrates and related substances}

The ability of the organism to utilize various substances as a source of carbon was determined by measuring the amount of gas and volatile acid produced from $25 \mathrm{ml}$. of medium containing $20 \%$ yeast water, $0.5 \mathrm{~g}$. of the substance under test, and $0.5 \mathrm{~g}$. calcium carbonate in long narrow tubes $(23 \times 1.7 \mathrm{~cm}$.) connected with water-filled gas burettes. The results are shown in Table 2. 
Table 2. Fermentation of various carbohydrates, alcohols and glucosides

\begin{tabular}{|c|c|c|c|c|}
\hline \multicolumn{5}{|c|}{$\left(7\right.$ days at $37^{\circ}$ and $\left.30^{\circ}\right)$} \\
\hline & \multicolumn{2}{|c|}{$\begin{array}{l}\text { Gas production } \\
\text { (ml.) }\end{array}$} & \multicolumn{2}{|c|}{$\begin{array}{l}\text { Volatile acid } \\
(\mathrm{ml} .0 \cdot 1 \mathrm{~N})\end{array}$} \\
\hline & $37^{\circ}$ & $30^{\circ}$ & $37^{\circ}$ & $30^{\circ}$ \\
\hline $\begin{array}{l}\text { Glucose, lactose, sucrose, } \\
\text { maltose, galactose, levu- } \\
\text { lose, arabinose, xylose, } \\
\text { mannose, starch }\end{array}$ & $195-270$ & $\mathbf{1 8 5 - 3 0 0}$ & $27 \cdot 5-42 \cdot 5$ & $29-41 \cdot 5$ \\
\hline $\begin{array}{l}\text { Raffinose, rhamnose, dex- } \\
\text { trin }\end{array}$ & $105-120$ & $95-160$ & $28-35 \cdot 5$ & $22-27 \cdot 5$ \\
\hline Salicin, pectin $(0 \cdot 3 \mathrm{~g})$. & $47-73$ & $42-97$ & $18-18 \cdot 5$ & $14-17$ \\
\hline $\begin{array}{l}\text { Glycerol, inulin, glycogen, } \\
\text { mannitol, sorbitol, ery- } \\
\text { thritol, cellulose }\end{array}$ & $0-5$ & 0 & $3-6$ & $1-6 \cdot 5$ \\
\hline Basal medium + inoculum & - & - & $\mathbf{3 \cdot 5}$ & $6 \cdot 0$ \\
\hline
\end{tabular}

Fermentation of glucose. Analyses of the fermentation products of glucose in the presence and absence of calcium carbonate are given in Table 3 . The inoculant was an active $24 \mathrm{hr}$. maize-tube culture. In the first series, $2 \%$ glucose was added to $600 \mathrm{ml}$. of $0.5 \%$ Difco yeast extract; in the second series $800 \mathrm{ml}$. of the same medium were taken, whereas in the third and fourth series $3 \%$ glucose was added to $600 \mathrm{ml}$. of yeast medium with the addition of $20 \mathrm{~g}$. of separately sterilized calcium carbonate.

Table 3. Products of fermentation of yeast glucose medium after 6-7 days' incubation at $37^{\circ}$

Glucose fermented (\%)

Titratable acidity

(ml. 0.1 N acid/10 ml.)

Butyric acid

Acetic acid

Lactic acid

Formic acid

Acetone

isoPropanol

Butanol

Ethanol

Acetylmethylcarbinol

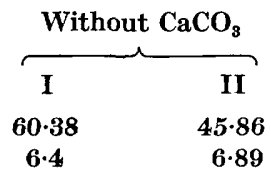

Products calculated in mmol./100 mmol. of glucose fermented

\begin{tabular}{|c|c|c|c|}
\hline $49 \cdot 4$ & $60 \cdot 6$ & $43 \cdot 5$ & $42 \cdot 1$ \\
\hline $51 \cdot 4$ & $59 \cdot 4$ & $47 \cdot 8$ & $63 \cdot 2$ \\
\hline $0 \cdot 0$ & $9 \cdot 4$ & $23 \cdot 9$ & $7 \cdot 1$ \\
\hline $0 \cdot 3$ & $2 \cdot 7$ & $0 \cdot 6$ & $1 \cdot 4$ \\
\hline $3 \cdot 2$ & $1 \cdot 8$ & $1 \cdot 0$ & $1 \cdot 5$ \\
\hline $5 \cdot 4$ & $6 \cdot 2$ & $3 \cdot 0$ & $1 \cdot 6$ \\
\hline $11 \cdot 9$ & $8 \cdot 5$ & $7 \cdot 1$ & $7 \cdot 4$ \\
\hline $34 \cdot 2$ & $45 \cdot 9$ & $15 \cdot 8$ & $14 \cdot 6$ \\
\hline $5 \cdot 8$ & Traces & $0 \cdot 3$ & $0 \cdot 6$ \\
\hline
\end{tabular}

Residual sugar was determined according to Lehmann-Maquenne-Schoorl (van der Haar, 1920).

Neutral solvents were distilled off from $200 \mathrm{ml}$. of neutralized fermented medium. $100 \mathrm{ml}$. of distillate were collected. The acetone content was estimated according to Goodwin's modification (Goodwin, 1920) of Messinger's method; isopropanol, by the method of Langlykke, Peterson \& McCoy (1935) and ethanol and butanol by Johnson's (1932) method.

GMI 2 
Volatile acids were determined from $50 \mathrm{ml}$. of the fermented medium acidified with phosphoric acid and distilled until about $12 \mathrm{ml}$. remained. $\mathrm{CO}_{2}$-free distilled water $(50 \mathrm{ml}$.) was then added to the distilling flask and distillation continued. This was repeated until all volatile acids were distilled over. The volatile acids were then determined according to Duclaux. The distillation constants were calculated from our own data obtained with pure acids.

Lactic acid was estimated directly on the fermented medium by the Fincke method (Official Methods, 1935).

Acetylmethylcarbinol was estimated on $200 \mathrm{ml}$. of the fermented medium according to Kluyver, Donker \& Visser 't Hooft's (1923) modification of Lemoigne's method.

\section{Fermentation of maize mash}

$5 \%$ maize mashes were fermented by the organism at $37^{\circ}$ and $30^{\circ}$. The inoculant used was $1 \mathrm{ml}$. of a young active culture. The analyses of the products of fermentation are recorded in Tables 4 and $\mathbf{5}$.

Table 4. Products of fermentation of $5 \%$ maize mashes at $37^{\circ}$

Series I and II: $600 \mathrm{ml}$. fermented mashes after 6 days. Series III: $200 \mathrm{ml}$. fermented mash after 7 days.

\begin{tabular}{|c|c|c|c|}
\hline \multirow{3}{*}{$\begin{array}{l}\% \text { starch fermented } \\
\text { Titratable acidity } \\
\text { (ml. } 0.1 \mathrm{~N} \text { acid } / 10 \mathrm{ml} .)\end{array}$} & I & II & III \\
\hline & $82 \cdot 79$ & $64 \cdot 22$ & $48 \cdot 69$ \\
\hline & $6 \cdot 89$ & $7 \cdot 40$ & $6 \cdot 25$ \\
\hline & \multicolumn{3}{|c|}{$\%$ on fermented starch } \\
\hline Butyric acid & $9 \cdot 14$ & $15 \cdot 11$ & $22 \cdot 88$ \\
\hline Acetic acid & $9 \cdot 49$ & $11 \cdot 33$ & 11.99 \\
\hline Lactic acid & $6 \cdot 49$ & $2 \cdot 5$ & - \\
\hline Formic acid & 0.03 & $0 \cdot 17$ & - \\
\hline Acetone & $5 \cdot 44$ & $1 \cdot 30$ & $0 \cdot 1 \dot{9}$ \\
\hline isoPropanol & 1.81 & 0.98 & 1.41 \\
\hline Butanol & $9 \cdot 42$ & $3 \cdot 12$ & $0 \cdot 0$ \\
\hline Ethanol & 5.02 & $7 \cdot 17$ & $6 \cdot 23$ \\
\hline Acetylmethylcarbinol & 0.29 & 0.23 & - \\
\hline Total neutral solvents & 21.98 & $12 \cdot 80$ & $7 \cdot 83$ \\
\hline
\end{tabular}

Table 5. Products of fermentation of $200 \mathrm{ml} . \mathbf{5} \%$ maize mash after 7 days at $30^{\circ}$

\begin{tabular}{lcc} 
& I & II \\
\% starch fermented & $\mathbf{6 1 \cdot 8 5}$ & $\mathbf{5 3 \cdot 3 7}$ \\
Titratable acidity & $\mathbf{8 \cdot 8}$ & $\mathbf{8 \cdot 3}$ \\
(ml. 0.1 N acid/10 mI.) & \multicolumn{2}{c}{$\%$ on fermented starch } \\
& $25 \cdot 46$ & $\mathbf{1 8 \cdot 3 0}$ \\
Butyric acid & $13 \cdot 35$ & $23 \cdot 71$ \\
Acetic acid & $0 \cdot 71$ & $3 \cdot 09$ \\
Acetone & $3 \cdot 00$ & $6 \cdot 04$ \\
Butanol & $11 \cdot 88$ & $6 \cdot 15$ \\
Ethanol & - & $0 \cdot 78$ \\
isoPropanol & $15 \cdot 59$ & $\mathbf{1 6 \cdot 0 6}$
\end{tabular}

The results of the analyses show that the main products of the fermentation of maize are butyric and acetic acid. It is evident, therefore, that the organism cannot be classified as a true butylic organism; more evidence on this matter is given below, in the discussion of its systematic relationships. 
Butyric acid and acetic acids are also the chief products of dissimilation of glucose. Fair amounts of ethanol are produced, small amounts of butanol, and slight amounts of acetone, isopropanol and acetylmethylcarbinol. The organism produces more ethanol in the absence of calcium carbonate. Complete fermentation of the glucose takes place when the acids produced are neutralized.

In interpreting the above data for the identification of the new chromogen, it will be observed that the organism has many characteristics in common with both the two closely related specific groups: the butyric group represented by Cl. butyricum Prazmowski, and the so-called butylic group represented by $\mathrm{Cl}$. acetobutylicum Weizmann, including the two known chromogens $\mathrm{Cl}$. felsineum and $\mathrm{Cl}$. roseum. The new organism resembles more closely the former group in morphology and in producing butyric acid rather than butanol; but it is a gelatin liquefier and none of the true butyrics is known to liquefy gelatin. Since the liquefaction of gelatin has been used so far as a diagnostic feature of the butylics, one cannot lightly consider the new organism as a pigmented variety of $\mathrm{Cl}$. butyricum, nor is there sufficient justification for regarding it as a pigmented variety of $\mathrm{Cl}$. acetobutylicum.

\section{COMPARISON WITH RELATED SPECIES}

To facilitate the identification of the pink organism, it is compared with the closely related butylic chromogens $\mathrm{Cl}$. felsineum and $\mathrm{Cl}$. roseum.

The salient characteristics common to all three chromogens are briefly: (1) pinkish to reddish pigmentation on nutrient agar; (2) orange to reddish discoloration of maize and potato mashes; (3) liquefaction of gelatin; (4) the fermentation of pectin to a certain extent; (5) production of acetone, butanol, butyric acid and acetylmethylcarbinol.

The features that distinguish the new chromogen from $\mathrm{Cl}$. felsineum and Cl. roseum are: (1) its partial diastatic action in maize mash, as against the complete diastatic activity of the butylics; (2) its appreciably lower yields of neutral fermentation products from carbohydrates; $(3)$ its inability to ferment inulin; (4) its failure to disintegrate potato tissue, whereas $\mathrm{Cl}$. felsineum completely digests potato tissue to a yellow slime, producing abundant gas and a butyl odour, and $\mathrm{Cl}$. roseum behaves similarly to $\mathrm{Cl}$. felsineum but forms a clear yellow liquid and bluish sediment; (5) its inability to reduce nitrates; (6) its optimum temperature of growth at $30^{\circ}$ as compared with $37^{\circ}$ for $\mathrm{Cl}$. felsineum and $\mathrm{Cl}$. roseum; (7) certain appreciable differences in pigmentation.

A closer comparison of the individual fermentation products provides further evidence of a difference between the three organisms. In Tables 6 and 7 , the yields of the major fermentation products obtained by the new organism W45 in a number of experiments are compared with those recorded for $\mathrm{Cl}$. roseum and $\mathrm{Cl}$. felsineum (Kluyver strain). The fact that $\mathrm{W} 45$ is a poor solvent producer from maize mash is clearly shown.

The production of isopropanol and acetylmethylcarbinol is noteworthy. W 45 produces isopropanol from carbohydrates, whereas, according to McCoy and co-workers, $\mathrm{Cl}$. roseum and $\mathrm{Cl}$. felsineum do not. Van der Lek (1930), 
also working with the Kluyver strain of $\mathrm{Cl}$. felsineum, found isopropanol in a few instances only. McCoy and co-workers do not record the production of acetylmethylcarbinol by $\mathrm{Cl}$. felsineum and $\mathrm{Cl}$. roseum; Van der Lek, however, observed its production from glucose by $\mathrm{Cl}$. felsineum. The new chromogen forms it too. Besides the results recorded in Tables 3 and 4, three confirmatory

Table 6. Fermentation of $5 \%$ maize by $\mathbf{W} 45$,

Cl. roseum* and $\mathrm{Cl}$. felsineum* at $37^{\circ}$

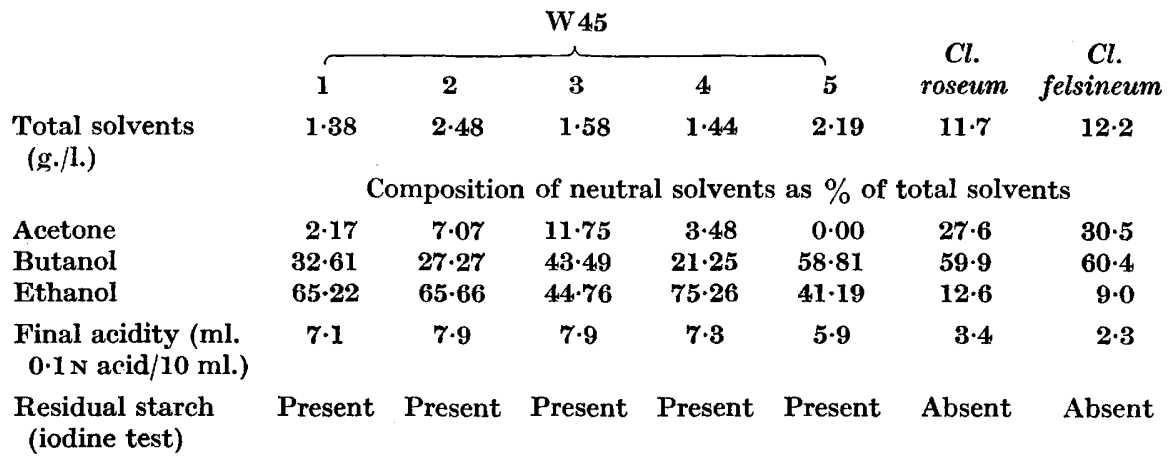

* Figures for $\mathrm{Cl}$. roseum and $\mathrm{Cl}$. felsineum taken from Langlykke et al. (1935).

Table 7. Fermentation of yeast-glucose by $\mathbf{W} 45$, Cl. roseum* and $\mathrm{Cl}$. felsineum* at $37^{\circ}$

\begin{tabular}{|c|c|c|c|c|c|}
\hline & \multicolumn{2}{|c|}{ W45 } & \multirow[b]{2}{*}{$\begin{array}{l}\text { Cl. roseum } \\
\text { strain } 42\end{array}$} & \multirow[b]{2}{*}{$\begin{array}{c}\text { Cl. roseum } \\
\text { strain } 43\end{array}$} & \multirow[b]{2}{*}{$\begin{array}{l}\text { Cl. felsineun } \\
\text { strain } 41\end{array}$} \\
\hline & $\mathbf{1}$ & 2 & & & \\
\hline \multirow{3}{*}{$\begin{array}{l}\text { Glucose fermented } \\
\text { Acidity (ml. } 0 \cdot 1 \mathrm{~N} \text { acid } / 10 \mathrm{ml} .)\end{array}$} & $60.4 \%$ & $45.9 \%$ & $56.5 \%$ & $46.5 \%$ & $79 \cdot 6 \%$ \\
\hline & $6 \cdot 4$ & $6 \cdot 9$ & $9 \cdot 85$ & $9 \cdot 05$ & $6 \cdot 70$ \\
\hline & \multicolumn{5}{|c|}{ Neutral volatile products, as \% of glucose fermented } \\
\hline Butanol & 4.9 & $3 \cdot 5$ & $4 \cdot 6$ & $\mathbf{2 \cdot 6}$ & $14 \cdot 4$ \\
\hline Ethanol & $8 \cdot 7$ & $11 \cdot 7$ & $\mathbf{3 \cdot 5}$ & $3 \cdot 1$ & $1 \cdot 8$ \\
\hline Acetone & $1 \cdot 0$ & 0.6 & 1.5 & $1 \cdot 0$ & $4 \cdot 4$ \\
\hline isoPropanol & $1 \cdot 8$ & $2 \cdot 1$ & - & - & - \\
\hline Total solvents & $16 \cdot 4$ & $17 \cdot 9$ & $9 \cdot 6$ & $6 \cdot 9$ & $20 \cdot 6$ \\
\hline
\end{tabular}

* Figures for $\mathrm{Cl}$. roseum and $\mathrm{Cl}$. felsineum taken from Langlykke et al. (1935).

flask experiments were made with $100 \mathrm{ml}$. of a $2 \%$ glucose nutrient medium. Two of the flasks containing calcium carbonate gave 3.4 and $6.5 \mathrm{mg}$. and the third flask without calcium carbonate gave $3.2 \mathrm{mg}$. of acetylmethylcarbinol.

Action on pectin. The new chromogen definitely ferments pectin (see Table 2), a characteristic shared by $\mathrm{Cl}$. roseum and $\mathrm{Cl}$. felsineum. When grown on carrot wedges, the organism causes a marked disintegration of the tissue ( $\mathrm{Pl}$. $1 \mathrm{C} \mathrm{2}$ ). Definite signs of softening and rotting are observed within $48 \mathrm{hr}$.

Microscopic examination of the softened tissues reveals that a certain amount of separation of the cells has occurred, but that the cell walls are left intact. On staining with ruthenium red, the stain is in many instances localized in certain places and not evenly distributed around the cell walls. This suggests that the pectic substances of the middle lamella cementing the cells together 
are attacked by the organism. Potato slopes on the other hand show no signs of disintegration (Pl. 1, C1). It is interesting to compare this with certain inoculation experiments carried out on potato and carrot slopes with strains of Cl. pectinovorum (Weizmann \& Hellinger, 1940). Two of the strains brought about a slow but perceptible breakdown of the potato tissue, but the carrot slope was left intact.

The ability of the new bacterium to attack pectin is of interest because of the claims made by various investigators that certain species of clostridia are the causal agents of retting; $\mathrm{Cl}$. felsineum is known to be a true retting organism.

Table 8. Comparative measurements of $\mathrm{W} 45, \mathrm{Cl}$. roseum and

\begin{tabular}{|c|c|c|c|}
\hline \multicolumn{4}{|c|}{ Cl. felsineum } \\
\hline & $\begin{array}{c}\text { W45 } \\
24 \text { hr. on maize } \\
(\mu .)\end{array}$ & $\begin{array}{l}\text { Cl. roseum } \\
24 \text { hr. on maize* } \\
\quad(\mu .)\end{array}$ & $\begin{array}{l}\text { Cl. felsineum } \dagger \\
(\mu .)\end{array}$ \\
\hline \multicolumn{4}{|l|}{ Rods: } \\
\hline $\begin{array}{l}\text { Limits of size } \\
\text { Average }\end{array}$ & $\begin{array}{l}2.6-13.0 \times 0.5-0.6 \\
5.6 \times 0.54\end{array}$ & $\begin{array}{l}3.2-4.3 \times 0.7-0.9 \\
3.9 \times 0.8\end{array}$ & $3.0-5.0 \times 0.3-0.4$ \\
\hline \multicolumn{4}{|l|}{ Clostridia: } \\
\hline $\begin{array}{l}\text { Limits of size } \\
\text { Average }\end{array}$ & $\begin{array}{l}4.5-8.0 \times 0.7-1.0 \\
5.8 \times 0.82\end{array}$ & $\begin{array}{l}5 \cdot 3-8 \cdot 8 \times 1 \cdot 1-1 \cdot 5 \\
6 \cdot 7 \times 1 \cdot 4\end{array}$ & - \\
\hline \multicolumn{4}{|l|}{ Spores: } \\
\hline $\begin{array}{l}\text { Limits of size } \\
\text { Average }\end{array}$ & $\begin{array}{l}2.0-2.4 \times 0.5-1.1 \\
2.2 \times 0.95\end{array}$ & $\begin{array}{l}2 \cdot 5-2 \cdot 8 \times 1 \cdot 2-1.3 \\
2 \cdot 7 \times 1 \cdot 2\end{array}$ & $2.3 \times 1 \cdot 5-2$ \\
\hline Spore position & Sub-terminal & Sub-terminal & Sub-terminal \\
\hline
\end{tabular}

Pigmentation. The new clostridium generally produces orange-red colonies on yeast glucose agar, but sometimes they may be faintly pink and deepen on standing under anaerobic conditions to a pale orange. The colour is more intense at the centre of the colony, where growth is thicker. On first isolation colonies showed the most intense pigmentation. After numerous subculturings, the colour was less and appeared irregularly. Some colonies develop pigmentation only after some weeks. Pigment production, however, always occurs on maize; on exposure to air, the colour fades in maize mashes. Intermittent subcultivation from maize mash on to yeast glucose agar appears to intensify the pigmentation.

Colonies of $\mathrm{Cl}$. roseum on beef peptone glucose agar are stated by McCoy $\&$ McClung (1935) to be orange-red; the colour darkens, on exposure to air to almost black, and a purplish pigment diffuses into the agar for several millimeters from the colonies. According to Ruschmann \& Bavendamm (1925), colonies of $\mathrm{Cl}$. felsineum on carrot juice agar are yellow-red, and the colour darkens on standing in the air to a dirty grey-brown and finally blackish brown. A purplish colour is said to develop from the surface downward in maize cultures of $\mathrm{Cl}$. roseum left standing in the air.

Morphology. Too much reliance should not be placed on the value of a comparison of the morphological data summarized in Table 8. The rods of Cl. roseum and $\mathrm{Cl}$. felsineum appear to be more regular than $\mathbf{W} 45$, whereas 
W 45 appears to be thinner than $C l$. roseum. Spores of $\mathbf{W} 45$ are smaller than the spores of $\mathrm{Cl}$. roseum and $\mathrm{Cl}$. felsineum. Ruschmann \& Bavendamm (1925) observed that Carbone \& Tomolato's $\mathrm{Cl}$. felsineum produced, on potato mash, long threads which broke up into cell-chains of many segments, and also double and single rods. This characteristic has frequently been observed with W 45 on various media.

Sporulation. When subcultured several times at $37^{\circ}$, the new organism loses its ability to sporulate, but quickly recovers it at $30^{\circ}$. This feature does not appear to be a characteristic of $\mathrm{Cl}$. felsineum or $\mathrm{Cl}$. roseum.

\section{Identity of the organism}

There is a certain resemblance between the new chromogen and the two butyl chromogens $\mathrm{Cl}$. felsineum and $\mathrm{Cl}$. roseum, but it is outweighed by the differences. The new bacterium is a butyric organism, but it is unusual in that it possesses a gelatinase. The organism is, therefore, recognized as a new Clostridium for which the name $\mathrm{Cl}$. aurantibutyricum is suggested.

\section{REFERENCES}

Bergey, D. H., Breed, R. S., Murray, E. G. D. \& Hitchens, A. P. (1939). Manual of Determinative Bacteriology. Baltimore: Williams and Wilkins Co. 5th ed.

Carbone, D. \& Tomolato, A. (1917). Staz. sper. Agric. ital. 50, 563.

Friedemann, T. E. \& Graeser, J. B. (1933). The determination of lactic acid. J. biol. Chem. 100, 291.

Goodwin, L. F. (1920). The analysis of acetone by Messinger's method. J. Amer. chem. Soc. 42, 39.

Johnson, M. J. (1932). Determination of small amounts of ethyl and butyl alcohols. Industr. Engng Chem. (Anal. ed.) 4, 20.

Kuuyver, A. J., Donker, H. J. L. \& Visser't Hooft, F. (1925). Ueber die Bildung von Acetylmethylcarbinol und 2, 3-Butylenglykol im Stoffwechsel der Hefe. Biochem. Z. 161, 361.

Langlykke, A. F., Peterson, W. H. \& McCoy, Elizabetu (1935). Products from the fermentation of glucose and arabinose by butyric acid anaerobes. $J$. Bact. $29,333$.

MCClung, L. S. (1942). Isolation of chromogenic spore forming anaerobic bacteria. J. Bact. 43, 35 (Abstract).

McCoy, Elizabetr \& McClung, L. S. (1935). Studies on anaerobic bacteria. VI. The nature and systematic position of a new chromogenic Clostridium. Arch. Mikrobiol. 6, 230.

Official and tentative methods of analysis of the Association of Official Agricultural Chemists, Washington (1935).

Ruschmann, G. \& Bavendamm, W. (1925). Zur Kenntnis der Röesterreger Bacillus felsineus Carbone und Plectridium pectinovorum (Bact. amylobacter, A.M. et Bredemann). Zbl. Bakt. Abt. 2, 64, 340.

VAN Der HAAR (1920). Monosaccharide und Aldehydesäuren, p. 122. Berlin: Gebr. Borntraeger.

VAN der Lek, J. B. (1930). Thesis, Delft.

Weizmann, Ch. \& Hellinger, Esther (1940). Studies on some strains of butyricacid-producing plectricidia isolated from hemp, jute and flax, J. Bact. 40,665. 


\section{Journal of General Microbiology, Vol. 1, No 2}

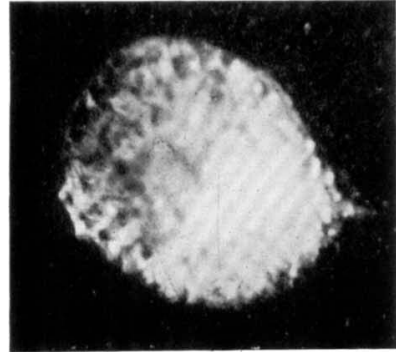

A. Colony of $\mathrm{Cl}$. aurantibutyricum. $48 \mathrm{hr}$. growth on yeast glucose agar under anaerobic conditions at $30^{\circ}$ $(\times 23)$.

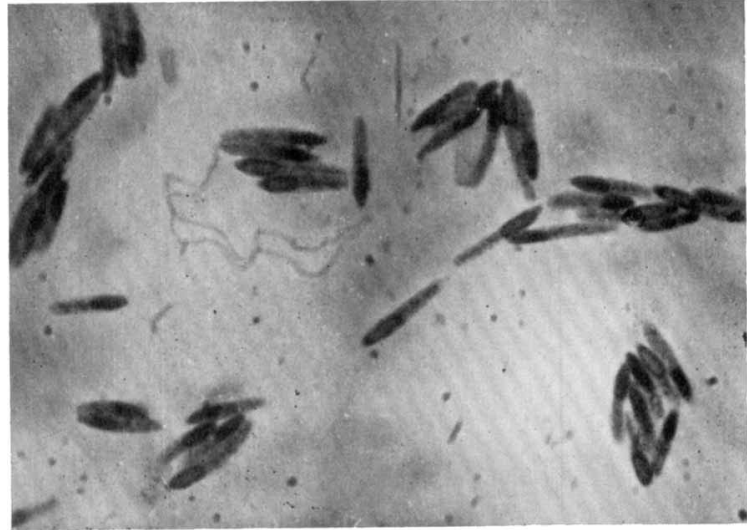

B. Clostridial forms from a 6 days old colony of $\mathrm{Cl}$. aurantibutyricum on yeast glucose agar at $30^{\circ}(\times 1440)$.

C. 1. Potato wedge, inoculated with $\mathrm{Cl}$. aurantibutyricum, scarcely attacked after 21 days. 2. Inoculated carrot wedge which has disintegrated and fallen into the aqueous solution below the constriction of the tube.
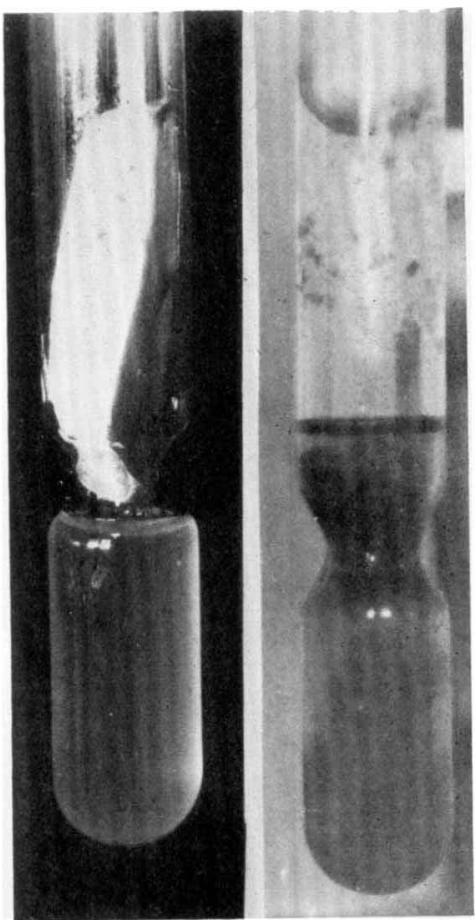

1

E. Helinger-Cl. aurantibutyricum (n.sp.): a pink butyric acin Closthidium. Plate 1 